\title{
Cultivar Variety and Added Potassium Influence the Nutraceutical and Antioxidant Content in Hydroponically Grown Basil (Ocimum basilicum L.)
}

\author{
Lilia Salas-Pérez ${ }^{1}$, Tiziana Fornari-Reale ${ }^{2}$, Pablo Preciado-Rangel ${ }^{3}$, José L. García-Hernández ${ }^{4}$, \\ Esteban Sánchez-Chávez ${ }^{5}$ and Enrique Troyo-Diéguez ${ }^{6, *}$ \\ 1 Gómez Palacio Polytechnic University, Gómez Palacio, Durango 35120, Mexico; lsalas@upgop.edu.mx \\ 2 Madrid Autonomous University (UAM-CEI-CSIC), 28049 Madrid, Spain; tiziana.fornari@uam.es \\ 3 Torreón Technological Institute (ITT), Torreón, Coahuila 27170, Mexico; ppreciador@yahoo.com.mx \\ 4 Juárez de Durango State University (UJED)-Agriculture and Zootechnics Faculty (FAZ), Venecia, \\ Durango 34000, Mexico; luis_garher@hotmail.com \\ 5 Center for Food and Development Research (CIAD-CONACYT), Chihuahua 33089, Mexico; \\ esteban@ciad.mx \\ 6 Center for Biological Research of Northwest México (CIBNOR), La Paz, Baja California Sur 23096, Mexico \\ * Correspondence: etroyo04@cibnor.mx; Tel.: +52-612-123-8484 (ext. 3442)
}

Received: 31 December 2017; Accepted: 24 January 2018; Published: 30 January 2018

\begin{abstract}
The potential impact of increased levels of potassium $\left(\mathrm{K}^{+}\right)$in hydroponic solution on the production of bioactive compounds, which provide added value to products, is relevant for local economy and human health. This research pursues assessing different levels of $\mathrm{K}^{+}$on the nutrition of basil, an important aromatic crop in the arid region of La Laguna, northern México, where water scarcity demands the conversion from open-field agriculture to hydroponics. A randomized complete block design with a factorial arrangement $(3 \times 4)$ was used to determine the content of nutraceutical components, including polyphenolic compounds, flavonoids, anthocyanins, vitamin C, chlorophylls, and the antioxidant capacity of three varieties of hydroponic basil, with four doses of $\mathrm{K}^{+}$in the nutrient solution, 7, 9, 11 and $13 \mathrm{mmol} \mathrm{L}^{-1}$. The analysis of variance showed significant differences $(p \leq 0.001)$ in most of the response variables, caused by the genotype and doses of $\mathrm{K}^{+}$. The antioxidant capacity of assessed cultivars was improved when doses of $\mathrm{K}^{+}$were increased in the nutrient solution. Furthermore, the antioxidant capacity was positively correlated to the content of flavonoids $(r=0.621)$, anthocyanins $(r=0.655)$ and total phenolic compounds $(r=0.549)$. In conclusion, the nutraceutical content was increased in basil when controlling $\mathrm{K}^{+}$in the nutrient solution.
\end{abstract}

Keywords: hydroponic basil; antioxidants; nutraceuticals; potassium nutrient

\section{Introduction}

The need to increase nutrients in crops to avoid deficiencies, which may affect yield, must motivate to ensure the development of feasible strategies for sustainable production [1]. On the other hand, current human lifestyle, characterized by nutrition disorders and stress, have increased the number of chronic diseases such as obesity, diabetes, cancer, cardiovascular diseases and neurological disorders, among others [2]. Therefore, it is necessary to join in a global effortm in matter of feed, health and environment, to produce safe foods, including high-quality nutritional supplements that promote health and reduce the risk of chronic diseases [3]. In regard to plant matrices, it is important to propose protocols based in biological systems to increase the content of nutrients in plants, specifying the proper use of resources and external inputs to reduce as far as possible the effects caused to the environment. In this sense, some authors have suggested that hydroponics system have practical 
applications, especially in conditions of low water availability, and its goal is to take advantage of production from the viewpoint of quality [4].

The hydroponic system allows control of the environmental conditions and eliminates the problem of soil disinfection, without the common imbalance of nutrients found in soil due to its heterogeneous distribution [5]. In addition, hydroponic systems production conditions provide reproducibility by uniform growth patterns and better homogeneity in the supply of nutrients to plants [6]. Potassium $\left(\mathrm{K}^{+}\right)$ is one of the abundant macronutrient in plants, with important effects on production and quality [7]. $\mathrm{K}^{+}$is present in plant tissues mostly in its water-soluble form, with physiological implications in cell maintenance and stomatal opening [8]. In addition, $\mathrm{K}^{+}$promotes rapid accumulation and translocation of carbohydrates and activates processes that are necessary for the conservation of plant water status and turgor pressure of cells [9].

Some studies report that $\mathrm{K}^{+}$, in addition to promoting the synthesis of amides and proteins, is also an enzyme activator [10]. Its function as enzymatic activator has been linked to the production of phytonutrients and thus, it has implications in the biochemical synthesis of secondary metabolism products of plants [9]. $\mathrm{K}^{+}$favors the increase of phenolic acids, flavonoids, anthocyanins, chlorophyll, carotenoids, lycopene and vitamins [11]. Those studies have been carried out with different plants under hydroponic conditions; nevertheless, studies of production of medicinal plants in hydroponic systems are scarce.

Therefore, this work was focused on basil (Ocimum basilicum L.), which it is an ornamental, culinary and medicinal spice belonging to the Lamiaceae family, cultivated worldwide and produced under a variety of growing conditions [12]. Basil is a plant widely studied for its wide variety of medicinal applications and, similar to other spices of this family, with a high antioxidant capacity and other important biological functions [13]. There is available information about the content of phytonutrients in different genotypes of basil; however, nutraceutical compounds and antioxidant capacity in hydroponic basil under control of potassium has been scarcely reported previously. Among the phytochemicals that have been studied in basil, Javanmardi et al. [14] reported phenolic compounds, flavonoids, vitamins and pigments. Moreover, this type of research is interesting because some disciplines of life sciences, such as resource management, environment, food and health, and others, should work jointly to find solutions and improvements in food production systems, as for example the generation of efficient sources of nutraceuticals by means of environmentally safe protocols, aimed to improving human welfare and health. The aim of this study was to determine a potential increase of the contents of nutraceutical compounds and antioxidant capacity of the basil cultivars "Sweet Lemon", "Red Rubin" and "Cinnamon", produced under hydroponic system with increased doses of $\mathrm{K}^{+}$.

\section{Materials and Methods}

\subsection{Study Area}

This work was carried out in the region known as "Comarca Lagunera", located within the geographical coordinates $24^{\circ} 30^{\prime}$ and $27^{\circ} \mathrm{N}$, and $102^{\circ} 00^{\prime}$ and $104^{\circ} 40^{\prime} \mathrm{W}$, on the border line between the states of Coahuila and Durango, Mexico. The Comarca Lagunera is a semi-arid area located in the north central part of Mexico, at an average altitude of $1100 \mathrm{~m}$, with an average rainfall of $250 \mathrm{~mm}$, and annual average temperature of $26.9^{\circ} \mathrm{C}$ [15].

\subsection{Experimental Site}

This work was carried out during the 2014 spring at "El Quemado", which is a cooperative community located in the California Farm, which belongs the Municipality of Gómez Palacio, Durango State, México. The experiment was performed in a greenhouse covered with a UV stabilized plastic film, and with an anti-insect mesh on lateral sides, with semi-automatic temperature regulator based on sidewall vents, from which, when open, cool replacement air enters and drops to the floor level. Temperature and humidity values were registered from 25 to $30{ }^{\circ} \mathrm{C}$ and from 70 to $80 \%$, 
respectively; total annual precipitation is $265.9 \mathrm{~mm}$ and September is the rainiest month, with $53.1 \mathrm{~mm}$ (Figure 1); solar daily radiation for the experimental period, March, April and May, was 6.18, 6.61, and $6.88 \mathrm{kWhm}^{-2} \mathrm{day}^{-1}$, and the monthly averaged daylight hours were 12.0, 12.7 and $13.3 \mathrm{~h}$, respectively $[16,17]$.

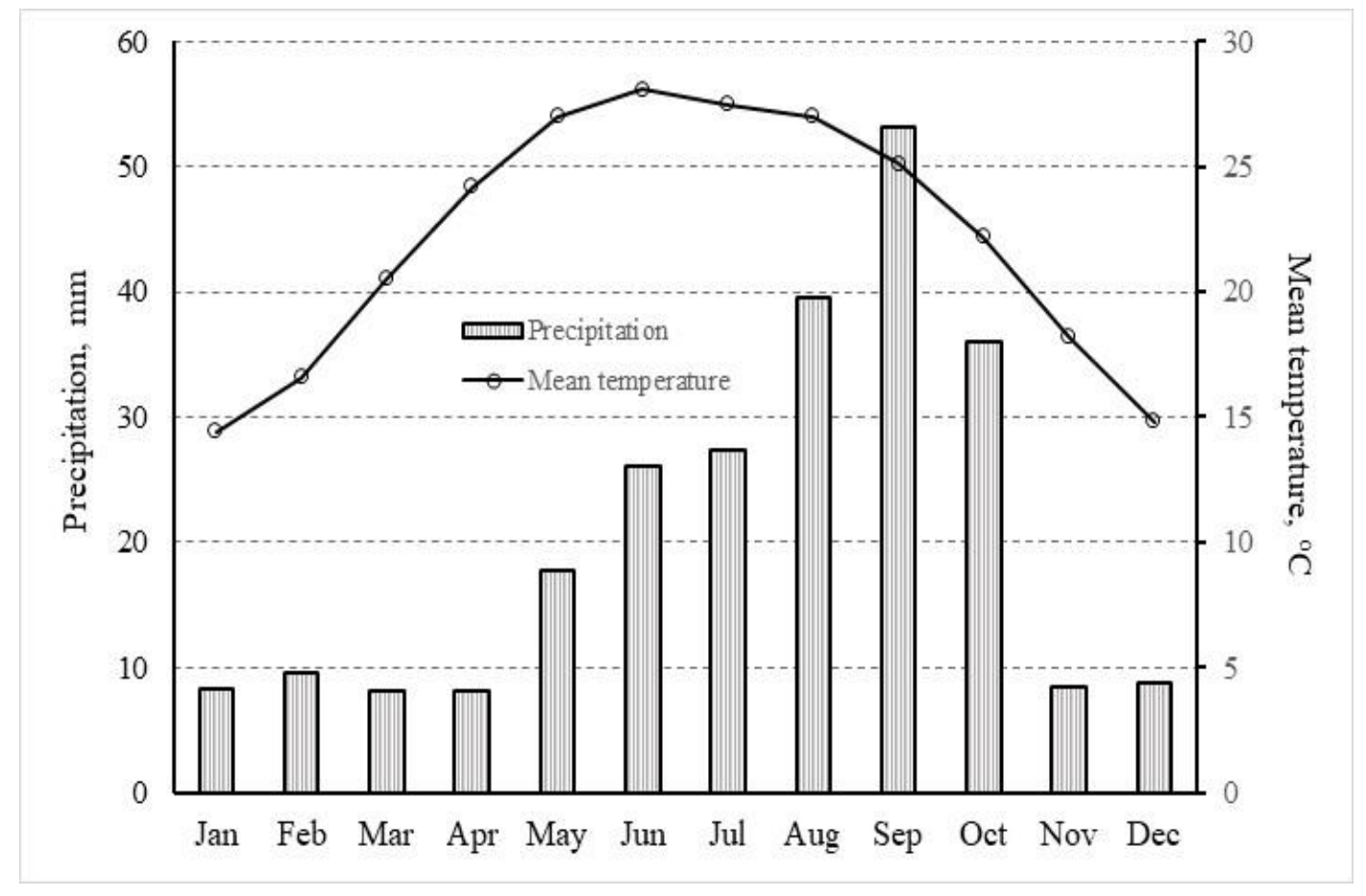

Figure 1. Monthly values of rainfall and temperature in Gómez Palacio, Durango State, Mexico.

\subsection{Plant Materials and Treatments}

Three cultivars of basil (Ocimum basilicum L.), "Sweet Lemon", "Cinnamon" and "Red Rubin", were selected for representing a wide range of morphological and genetic characteristics [18]. Basil seeds were obtained as a donation from the Juárez Durango State University (UJED). Planting took place in polystyrene germination trays with 250 cavities (three seeds per cavity) filled with perlite $\left(\right.$ Environment ${ }^{\circledR}$ ), on 15 March 2014. Trays were watered twice a day with tap water. Seedlings developed 3-4 true leaves and a height of 0.10-0.15 m 21 Days After Sowing (DAS) (8 April 2014), then were transferred to black plastic pots ( $3.78 \mathrm{~L}$ capacity) containing $0.28 \mathrm{~L}$ of previously washed gross sand to allow drainage and $3.5 \mathrm{~L}$ of a mixture of sand:perlite (80:20). Sand was obtained from the bed of the Nazas River. A solarization process was applied to disinfect the sand, which is a method of using solar heat for controlling soil-borne plant pathogens including fungi, bacteria, nematodes, and insect, as well as mite pests along with weed seed and seedlings by mulching the substrate and covering with a transparent polyethylene cover, to retain solar energy.

Seedlings were placed in a randomized complete block design with six replicates per dose of $\mathrm{K}^{+}$ applied to each genotype, with $n=72$ plants (Table 1); each treatment consisted of a pot with one plant (one pot per replicate), with 24 experimental units per genotype. Treatments were designed modifying the nutrient solution of Steiner [19], increasing the level of $\mathrm{K}^{+}$to 7, 9, 11 and $13 \mathrm{mmol} \mathrm{L}^{-1}$ (or meq $\mathrm{L}^{-1}$ ). A treatment with no increase of $\mathrm{K}^{+}\left(0 \mathrm{mmol} \mathrm{L}{ }^{-1}\right)$ was not included, as $\mathrm{K}^{+}$has an important role in providing the correct ionic environment for metabolic processes and is not replaceable in its cytoplasmic functions. In this sense, $\mathrm{K}^{+}$content in plain water (Table 2) was not considered as the baseline, as plants would face deficiency.

The experimental nutrient solution contained (in $\mathrm{mg} \cdot \mathrm{L}^{-1}$ ) $8 \mathrm{Fe}, 0.865 \mathrm{~B}, 1.6 \mathrm{Mn}, 0.023 \mathrm{Zn}, 0.11 \mathrm{Cu}$ and $0.5 \mathrm{Mo}$ (Table 2), and its $\mathrm{pH}$ and osmotic potential were adjusted to 5.5 and $-0.073 \mathrm{MPa}$, 
respectively. The nutrient solution was formulated using commercial fertilizers of high solubility, available in the local market; its application was initiated at transplanting date and was repeated twice a day (9:00 and 18:00) at a rate of $0.5 \mathrm{~L}$ per pot. In addition to these applications, plants were also irrigated twice a day (12:00 and 15:00) based on the water needs of the plant, to reach field capacity. Harvest was carried out 40 DAS (18 May 2014). Then, plants were taken to the Biochemistry Lab at Gómez Palacio Politechnic University for their preparation and analysis.

Table 1. Factorial experiment in a randomized blocks design $(n=72)$.

\begin{tabular}{|c|c|c|c|c|c|c|c|c|c|c|c|c|c|c|c|c|c|c|}
\hline \multirow{2}{*}{$\mathrm{K}^{+}$Dose } & \multicolumn{18}{|c|}{ Genotypes Replicates Distribution } \\
\hline & \multicolumn{18}{|c|}{$\mathrm{G}_{1,2,3}$} \\
\hline \multirow{2}{*}{$\mathrm{D}_{1}$} & $\mathrm{G}_{1}$ & $\mathrm{G}_{3}$ & $\mathrm{G}_{2}$ & $\mathrm{G}_{3}$ & $\mathrm{G}_{1}$ & $\mathrm{G}_{2}$ & $\mathrm{G}_{2}$ & $\mathrm{G}_{3}$ & $\mathrm{G}_{1}$ & $\mathrm{G}_{2}$ & $\mathrm{G}_{3}$ & $\mathrm{G}_{1}$ & $\mathrm{G}_{3}$ & $\mathrm{G}_{1}$ & $\mathrm{G}_{2}$ & $\mathrm{G}_{1}$ & $\mathrm{G}_{2}$ & $\mathrm{G}_{3}$ \\
\hline & $\mathrm{D}_{1}$ & $\mathrm{D}_{1}$ & $\mathrm{D}_{1}$ & $\mathrm{D}_{1}$ & $\mathrm{D}_{1}$ & $\mathrm{D}_{1}$ & $\mathrm{D}_{1}$ & $\mathrm{D}_{1}$ & $\mathrm{D}_{1}$ & $\mathrm{D}_{1}$ & $\mathrm{D}_{1}$ & $\mathrm{D}_{1}$ & $\mathrm{D}_{1}$ & $\mathrm{D}_{1}$ & $\mathrm{D}_{1}$ & $\mathrm{D}_{1}$ & $\mathrm{D}_{1}$ & $\mathrm{D}_{1}$ \\
\hline \multirow{2}{*}{$D_{3}$} & $\mathrm{G}_{1}$ & $\mathrm{G}_{3}$ & $\mathrm{G}_{2}$ & $\mathrm{G}_{3}$ & $\mathrm{G}_{1}$ & $\mathrm{G}_{2}$ & $\mathrm{G}_{2}$ & $\mathrm{G}_{3}$ & $\mathrm{G}_{1}$ & $\mathrm{G}_{2}$ & $\mathrm{G}_{3}$ & $\mathrm{G}_{1}$ & $\mathrm{G}_{3}$ & $\mathrm{G}_{1}$ & $\mathrm{G}_{2}$ & $\mathrm{G}_{1}$ & $\mathrm{G}_{2}$ & $\mathrm{G}_{3}$ \\
\hline & $\mathrm{D}_{3}$ & $D_{3}$ & $D_{3}$ & $\mathrm{D}_{3}$ & $\mathrm{D}_{3}$ & $\mathrm{D}_{3}$ & $\mathrm{D}_{3}$ & $D_{3}$ & $D_{3}$ & $D_{3}$ & $D_{3}$ & $\mathrm{D}_{3}$ & $\mathrm{D}_{3}$ & $\mathrm{D}_{3}$ & $\mathrm{D}_{3}$ & $\mathrm{D}_{3}$ & $\mathrm{D}_{3}$ & $\mathrm{D}_{3}$ \\
\hline \multirow{2}{*}{$\mathrm{D}_{2}$} & $\mathrm{G}_{1}$ & $\mathrm{G}_{3}$ & $\mathrm{G}_{2}$ & $\mathrm{G}_{3}$ & $\mathrm{G}_{1}$ & $\mathrm{G}_{2}$ & $\mathrm{G}_{2}$ & $\mathrm{G}_{3}$ & $\mathrm{G}_{1}$ & $\mathrm{G}_{2}$ & $\mathrm{G}_{3}$ & $\mathrm{G}_{1}$ & $\mathrm{G}_{3}$ & $\mathrm{G}_{1}$ & $\mathrm{G}_{2}$ & $\mathrm{G}_{1}$ & $\mathrm{G}_{2}$ & $\mathrm{G}_{3}$ \\
\hline & $\mathrm{D}_{2}$ & $\mathrm{D}_{2}$ & $\mathrm{D}_{2}$ & $\mathrm{D}_{2}$ & $\mathrm{D}_{2}$ & $\mathrm{D}_{2}$ & $\mathrm{D}_{2}$ & $\mathrm{D}_{2}$ & $\mathrm{D}_{2}$ & $\mathrm{D}_{2}$ & $\mathrm{D}_{2}$ & $\mathrm{D}_{2}$ & $\mathrm{D}_{2}$ & $\mathrm{D}_{2}$ & $\mathrm{D}_{2}$ & $\mathrm{D}_{2}$ & $\mathrm{D}_{2}$ & $\mathrm{D}_{2}$ \\
\hline \multirow{2}{*}{$\mathrm{D}_{4}$} & $\mathrm{G}_{1}$ & $\mathrm{G}_{3}$ & $\mathrm{G}_{2}$ & $\mathrm{G}_{3}$ & $\mathrm{G}_{1}$ & $\mathrm{G}_{2}$ & $\mathrm{G}_{2}$ & $\mathrm{G}_{3}$ & $\mathrm{G}_{1}$ & $\mathrm{G}_{2}$ & $\mathrm{G}_{3}$ & $\mathrm{G}_{1}$ & $\mathrm{G}_{3}$ & $\mathrm{G}_{1}$ & $\mathrm{G}_{2}$ & $\mathrm{G}_{1}$ & $\mathrm{G}_{2}$ & $\mathrm{G}_{3}$ \\
\hline & $\mathrm{D}_{4}$ & $\mathrm{D}_{4}$ & $\mathrm{D}_{4}$ & $\mathrm{D}_{4}$ & $\mathrm{D}_{4}$ & $\mathrm{D}_{4}$ & $\mathrm{D}_{4}$ & $\mathrm{D}_{4}$ & $\mathrm{D}_{4}$ & $\mathrm{D}_{4}$ & $\mathrm{D}_{4}$ & $\mathrm{D}_{4}$ & $\mathrm{D}_{4}$ & $\mathrm{D}_{4}$ & $\mathrm{D}_{4}$ & $\mathrm{D}_{4}$ & $\mathrm{D}_{4}$ & $\mathrm{D}_{4}$ \\
\hline
\end{tabular}

Table 2. Chemical composition of the experimental solution and used water for solution.

\begin{tabular}{cccccccccccc}
\hline Solution & $\mathbf{N}$ & $\mathbf{P}$ & $\mathbf{K}^{+}$ & $\mathbf{C a}^{++}$ & $\mathbf{M g}^{++}$ & $\mathbf{M n}$ & $\mathbf{C u}$ & $\mathbf{M o}$ & $\mathbf{F e}$ & $\mathbf{B}$ & $\mathbf{Z n}$ \\
\hline Water & 7.67 & nd & 0.22 & 23 & 0.95 & na & na & na & na & na & na \\
ENS & 190.6 & 34 & $\mathrm{w}, \mathrm{x}, \mathrm{y}, \mathrm{z}$ & 125 & 27 & 1.6 & 0.11 & 0.5 & 8 & 0.865 & 0.023 \\
\hline
\end{tabular}

ENS: Experimental nutrient solution; $w, x, y, z$. are experimental doses of $273,351,429$, and $507 \mathrm{mg} \mathrm{L}^{-1}$ or 7, 9, 11 , and $13 \mathrm{mmol} \mathrm{L}^{-1}$, respectively; na = non-available

\subsection{Sample Preparation for Nutraceutical Compounds and Antioxidant Capacity Analyses}

Fresh basil was washed with water, placed in brown paper and dried at room temperature $\left(20 \pm 2{ }^{\circ} \mathrm{C}\right)$ for 15 days. Samples were ground in a blender (Hamilton Beach, Glen Alan, VA, USA) and stored at $5{ }^{\circ} \mathrm{C}$ to obtain extracts; extraction was carried out by adding $2 \mathrm{~g}$ of sample in $100 \mathrm{~mL}$ of ethanol. A "Stuart" type stirrer was used to keep mixture under agitation for $24 \mathrm{~h}$ at $30^{\circ} \mathrm{C}$, then the ethanol was evaporated with rotavapor (Buchi, Model-210, Beijing, China) in a water bath at $35-40^{\circ} \mathrm{C}$. The extracts obtained were stored in refrigerator until analysis.

\subsection{Chemicals}

Reagents for analyses (Sigma-Aldrich Corp., St. Louis MO, 63178 USA). were Folin-Ciocalteu reactive, gallic acid, $\mathrm{NaCO}_{3}$, quercetin reactive (3,3',4'5,7-Pentahydroxy-flavone), $\mathrm{NaNO}_{2} 5 \%$, $\mathrm{AlCl} \cdot \mathrm{H}_{2} \mathrm{O} 10 \%, \mathrm{NaOH} 1 \mathrm{M}$, kuromanin chloride, $\mathrm{HCl}$, phosphate-citrate buffer, 2,6 dichloroindophenol, ascorbic acid, Trolox, 2,2-Diphenil-1-pycril hydrazyl hydrate (DPPH, 95\% purity), ethanol and methanol. All chemicals were purchased from

\subsection{Determination of Total Phenolic Compounds}

Total phenolic content was measured using a modification of Folin-Ciocalteu method [20]. For this purpose, $30 \mu \mathrm{L}$ of extract were mixed with $270 \mu \mathrm{L}$ of distilled water in a test tube. Next, a volume of $1.5 \mathrm{~mL}$ of Folin-Ciocalteu reagent (Sigma-Aldrich, St. Louis, MO, USA) diluted (1:15) was added to mixture, with stirring vortexed for $10 \mathrm{~s}$. After $5 \mathrm{~min}, 1.2 \mathrm{~mL}$ of sodium carbonate $(7.5 \% w / v)$ was added and stirred for $10 \mathrm{~s}$. The solution was placed in water bath at $45^{\circ} \mathrm{C}$ for $15 \mathrm{~min}$, and then allowed to cool to room temperature. Absorbance of the solution was read at $765 \mathrm{~nm}$ on a Genesys 10UV spectrophotometer (Madison, WI, USA). Phenolic content was calculated using a calibration curve 
using gallic acid as standard, and the results were reported in $\mathrm{mg}$ of gallic acid equivalent per $\mathrm{g}$ of extract (mg GAE/g extract). Analyses were performed in triplicate, and the obtained mean value was used in the $\mathrm{G} \times \mathrm{KD}$ interaction study.

\subsection{Total Flavonoids Test}

The total flavonoid content was determined using a colorimetric method proposed by Zhishen et al. [21]. For this purpose, $250 \mu \mathrm{L}$ of the ethanolic extract was mixed with $1.25 \mathrm{~mL}$ distillated water in a test tube followed by addition of $75 \mu \mathrm{L}$ of $5 \% \mathrm{NaNO}_{2}$ solution. After $5 \mathrm{~min}, 150 \mu \mathrm{L}$ of $10 \%$ $\mathrm{AlCl}_{3} \cdot \mathrm{H}_{2} \mathrm{O}$ solution were added and allowed to stand for another $6 \mathrm{~min}$ before a volume of $500 \mu \mathrm{L}$ of $1 \mathrm{M} \mathrm{NaOH}$ was added, as well as an additional $275 \mu \mathrm{L}$ distillated water. All components were mixed by vortexing. The absorbance was measured immediately at $510 \mathrm{~nm}$ using a spectrophotometer (Genesys 10UV). The obtained results were expressed as $\mathrm{mg}$ of quercetin equivalents per $\mathrm{g}$ of extract (mg QE/g extract). Analyses were performed in triplicate, and the obtained mean value was used in the consequent $\mathrm{G} \times \mathrm{KD}$ interaction study.

\subsection{Anthocyanins Content}

For anthocyanin analysis, dried samples were extracted into $0.2 \mathrm{M}$ hydrochloric acid in methanol by a periodic shaking method; acidified methanol $(0.5 \mathrm{~mL})$ was added to the dried basil. Mixture was shaken for $40 \mathrm{~min}$ at room temperature and centrifuged at 13,200 rpm for $30 \mathrm{~min}$, and then the supernatant was removed. This procedure was repeated two additional times; all supernatants were combined and stored at $-80^{\circ} \mathrm{C}$. Total anthocyanin concentrations were determined in each cultivar using a spectrometric method developed by Abdel-Aal and Hucl [22]. The absorbance of the methanolic extract was measured at $535 \mathrm{~nm}$ versus an acidified methanol ( $15 \%$ hydrochloric acid, $v / v)$ blank. Measures were compared to a calibration curve prepared with kuromanin chloride, ranging from 2.5 to $25 \mathrm{mg} \mathrm{L}^{-1}$. Final observations were reported in $\mathrm{mg}$ of anthocyanin equivalents per $\mathrm{g}$ of extract (AE mg/g extract). Analyses were carried out in triplicate; the obtained mean was considered in the $\mathrm{G} \times \mathrm{KD}$ interaction study.

\subsection{Chlorophyll}

The chlorophyll relative content (SPAD value) was determined by means of SPAD 501 chlorophyll meter (Konica Minolta, Tokyo, Japan). Seven representative leaves were used with 2-3 displays of measurement each and the mean value was calculated. This method was intended to overcome the influence of a non-uniform distribution of chlorophyll in the leaf, and hence producing more representative data [23]. Analyses were performed in triplicate, and the obtained mean value was used in the $G \times K D$ interaction study.

\subsection{Vitamin C}

The ascorbic acid content was measured using a modified method of Davis and Masten [24]; accordingly, fresh leaf samples $(1 \mathrm{~g})$ were extracted in $1 \%$ of phosphate-citrate buffer $(2 \mathrm{~mL}, \mathrm{pH} 3.5)$ using a chilled pestle and mortar, and then the homogenate was filtered. The filtrate was added to the $1 \mathrm{~mL}$ of $1.7 \mathrm{mM}$ 2,6-dichloroindophenol (2,6-DCPIP) in a $3 \mathrm{~mL}$ cuvette. The absorbance at $520 \mathrm{~nm}$ was read within $10 \mathrm{~min}$ of mixing the reagents; the extraction buffer was a blank L-ascorbic acid, as a standard. Vitamin C was recorded as mg Ascorbic Acid per g of Dry Weight (mg AA/g DW). Analyses were performed in triplicate, and the mean value was used in the $G \times K D$ interaction study.

\subsection{Total Antioxidant Capacity}

The total antioxidant capacity of samples was determined according to the method of Brand-Williams et al. [25], with slight modifications. The solution of free radical 1,1-diphenyl-2-picryl-hidrazilo (DPPH+) (Aldrich, St. Louis, MO, USA) was prepared in a foil-covered 
flask with DPPH $5 \mathrm{mg} / 100 \mathrm{~mL}$ of ethanol analytical grade. Mixture was vigorously stirred and the flask covered and kept to prevent rapid degradation. A $300 \mu \mathrm{L}$ sample of the diluted extract and $1200 \mu \mathrm{L}$ of distilled water were stirred at $3000 \mathrm{rpm}$ for $10 \mathrm{~s}$, in triplicate. One milliliter of DPPH+ was added and again vortexed at $3000 \mathrm{rpm}$ for $10 \mathrm{~s}$. Readings were made at $517 \mathrm{~nm}$ after $90 \mathrm{~min}$. The total antioxidant capacity was calculated using a standard curve with the reference antioxidant Trolox and results were expressed in $\mu \mathrm{M}$ Trolox per g of extract ( $\mu \mathrm{M}$ Trolox/g extract). Analyses were performed in triplicate, and the mean value was used in the $\mathrm{G} \times \mathrm{KD}$ interaction study; statistical analyses were carried out using the software SAS version 9.2 (Statistical Analysis System, North Carolina State University, Raleigh, NC, USA) [26].

\section{Results}

\subsection{Total Phenolic Compounds and Flavonoids Content}

The total phenolic compounds (TPC) showed highly significant differences $(p \leq 0.001)$, caused by genotype $(G)$ and doses of $\mathrm{K}^{+}(\mathrm{DK})$. Table 3 shows the TPC determined in the samples (mean values obtained for each factor and doses). "Sweet Lemon" genotype showed the highest phenolic content (13.53 mg GAE/g extract), significantly different to "Cinnamon" and "Red Rubin" cultivars (12.51 and $12.30 \mathrm{mg} \mathrm{GAE} / \mathrm{g}$ extract, respectively). In relation to the DK factor, it was observed that the higher was the DK value, the higher was the content of phenolic compounds. In this sense, the highest TPC (14.80 mg GAE/g extract) was obtained with $13 \mathrm{mmol} \cdot \mathrm{L}^{-1}$. According to the gained results, $\mathrm{G}$ and DK affected the flavonoid content with highly significant statistical differences $(p \leq 0.001)$ (Table 2). For G, the greatest values of total flavonoids were observed for "Cinnamon" and "Red Rubin" cultivars (6.15 and $6.09 \mathrm{mg} \mathrm{QE} / \mathrm{g}$ extract, respectively), which were significantly different to the lowest value obtained for "Sweet Lemon" (5.85 mg QE/g extract). For the DK factor, the values obtained for total flavonoids varied from 5.38 to $6.64 \mathrm{mg} \mathrm{QE} / \mathrm{g}$ extract, within the interval 7 to $13 \mathrm{mmol} \cdot \mathrm{L}^{-1}$, respectively, with a similar response to that observed with phenolic compounds, i.e., a linear increase of the flavonoid content with the DK increase, as demonstrated by the $R^{2}$ values for the three cultivars (Table 3 ).

Table 3. Effect of genotype $(G)$, doses of $\mathrm{K}^{+}(\mathrm{DK})$, and interaction $(\mathrm{G} \times \mathrm{DK})$ on nutraceutical components of hydroponic basil.

\begin{tabular}{|c|c|c|c|c|c|c|}
\hline \multirow{2}{*}{ Factor } & \multirow{2}{*}{ Cultivar } & TPC & TF & A & $\mathrm{Ch}$ & vC \\
\hline & & mg GAE/g Extract & mg QE/g Extract & mg AE/g Extract & Units SPAD & mg AA/g DW \\
\hline \multirow[t]{4}{*}{ G } & SL & $13.53^{\mathrm{a}}$ & $5.85^{\mathrm{b}}$ & $0.69^{\mathrm{b}}$ & $38.16^{\mathrm{a}}$ & $0.18^{\mathrm{a}}$ \\
\hline & $R R$ & $12.30^{\mathrm{b}}$ & $6.09^{a}$ & $0.72^{\mathrm{a}}$ & $32.50^{\mathrm{b}}$ & $0.18^{a}$ \\
\hline & $\mathrm{CN}$ & $12.51^{\mathrm{b}}$ & $6.15^{\mathrm{a}}$ & $0.74^{\mathrm{a}}$ & $40.00^{\mathrm{a}}$ & $0.18^{a}$ \\
\hline & \multicolumn{6}{|c|}{ Dose, $\mathrm{mmol} \mathrm{L}^{-1}$} \\
\hline DK & 7 & $10.81^{\mathrm{d}}$ & $5.38^{\mathrm{d}}$ & $0.64^{\mathrm{d}}$ & $35.88^{a}$ & $0.17^{\mathrm{b}}$ \\
\hline \multirow{3}{*}{$\left(\mathrm{mmol} \cdot \mathrm{L}^{-1}\right)$} & 9 & $12.14^{\mathrm{c}}$ & $5.83^{c}$ & $0.69^{\mathrm{c}}$ & $34.18^{a}$ & $0.18^{\mathrm{a}}$ \\
\hline & 11 & $13.38^{b}$ & $6.25^{b}$ & $0.74^{b}$ & $36.02^{a}$ & $0.18^{a}$ \\
\hline & 13 & $14.80^{\mathrm{a}}$ & $6.64^{\mathrm{a}}$ & $0.79^{a}$ & $35.82^{a}$ & $0.18^{a}$ \\
\hline $\mathrm{G} \times \mathrm{DK}$ & & $* *$ & ns & ns & ns & $* *$ \\
\hline
\end{tabular}

G: Genotypes - SL: "Sweet Lemon"; RR: "Red Rubin"; CN: “Cinnamon"; DK: doses of added K+; TPC: Total Phenolic compounds; GAE: Gallic Acid Equivalent; TF: Total Flavonoids; QE: Quercetin; A: Anthocyanins; AE: Anthocyanin Equivalent; Ch: SPAD chlorophyll units (SPAD Value obtained by Minolta ${ }^{\mathrm{R}}$ SPAD 501 Chlorophyll meter); VC: Vitamin C; AA: Ascorbic Acid; DW: dry weight; G $\times$ DK: factors interaction. Different letter in the same column denotes significant differences according to Tukey $(p \leq 0.05)$; ns: non-significant; ${ }^{* *}$ : highly significant $p \leq 0.001$.

\subsection{Anthocyanins Content}

The obtained results suggest that G and DK exerted highly significant effect $(p \leq 0.001)$ on the anthocyanins content in the analyzed plants (Table 3). "Cinnamon" and "Red Rubin" showed the highest values of anthocyanins with 0.74 and $0.72 \mathrm{mg}$ of anthocyanin equivalent per $\mathrm{g}$ of extract (mg AE/g extract), respectively. "Sweet Lemon" showed the lowest content, $0.69 \mathrm{mg} \mathrm{AE} / \mathrm{g}$ extract. 


\subsection{Chlorophylls}

A highly significant effect was found for G $(p \leq 0.001)$ but not for DK (Table 2). "Cinnamon" and "Sweet Lemon" showed 40.00 and 38.16 SPAD units, respectively, followed by "Red Rubin" with 32.50 units.

\subsection{Vitamin C}

The content of vitamin $C$ showed highly significant differences with respect to the doses of $\mathrm{K}^{+}$ but not to $\mathrm{G}(p \leq 0.001)$ (Table 3). The highest content of vitamin $\mathrm{C}$ was obtained with a $\mathrm{K}^{+}$dose of $9 \mathrm{mmol} \cdot \mathrm{L}^{-1}$, followed by 11 and $13 \mathrm{mmol} \cdot \mathrm{L}^{-1}(0.18 \mathrm{mg} \mathrm{AA} / \mathrm{g} \mathrm{DW})$, and the lowest value was obtained with $7 \mathrm{mmol} \cdot \mathrm{L}^{-1}(0.17 \mathrm{mg} \mathrm{AA} / \mathrm{g}$ DW).

The interaction $G \times D K$ was significant, suggesting that DK affects the content of vitamin $C$ in the studied cultivars. Figure 2 shows that the dose $7 \mathrm{mmol} \cdot \mathrm{L}^{-1}$ caused significant differences in the vitamin $C$ content of each cultivar, with the highest content evidenced by the "Red Rubin" cultivar. In this context, an increase in the content of vitamin $C$ in the three cultivars using $\mathrm{K}^{+}$doses from 9 to $13 \mathrm{mmol} \cdot \mathrm{L}^{-1}$ was observed, although "Sweet Lemon" showed a slight increase with $9 \mathrm{mmol} \cdot \mathrm{L}^{-1}$, below "Cinnamon" and "Red Rubin" cultivars.

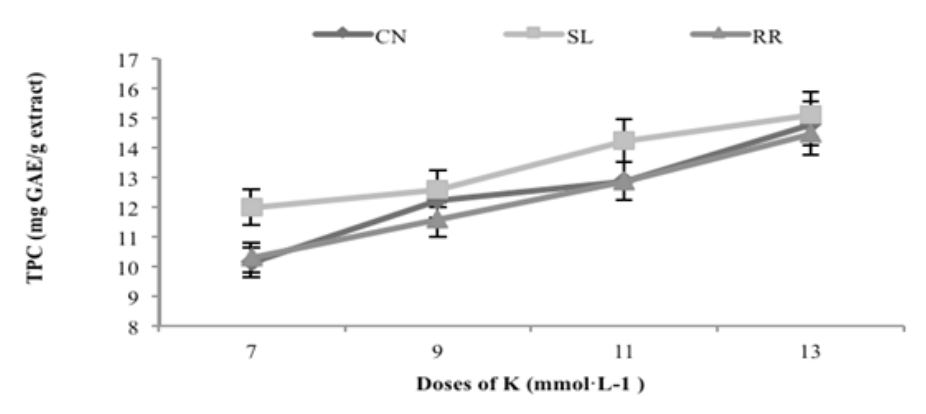

(a)

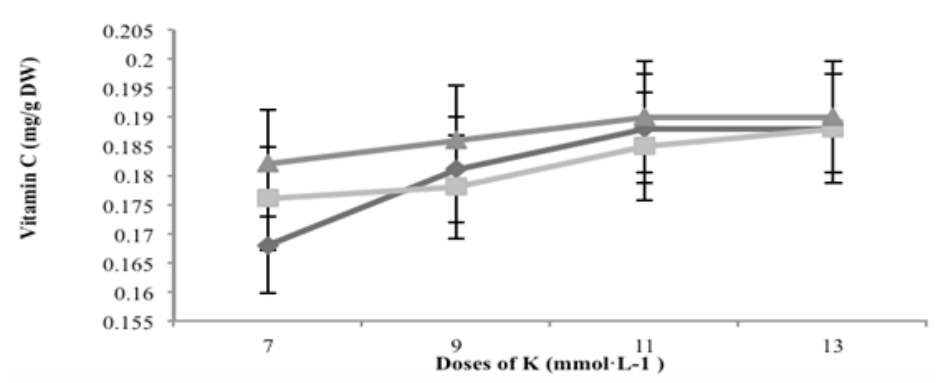

(b)

Figure 2. (a) Effects caused by the interaction of genotype and doses of $\mathrm{K}^{+}(\mathrm{G} \times \mathrm{DK})$ for the Total Phenolic Compounds (TPC) of hydroponic basil; (b) Effects caused by the interaction of genotype and doses of $\mathrm{K}^{+}(\mathrm{G} \times \mathrm{DK})$ for the content of Vitamin C of hydroponic basil; CN: "Cinnamon"; SL: "Sweet Lemon"; RR: “Red Rubin”. GAE: Gallic Acid Equivalent. Interval bars are standard error.

\subsection{Correlation Analysis}

To elucidate the effects caused by cultivars (G), we carried out principal components analysis (PCA), which results indicate that the Principal Component 1 (PC1) assumed most of the variance, estimated at $97.6 \%$, while PC2 only reflected $2.4 \%$ of the difference. PC1 is expressed as:

$$
\mathrm{PC} 1=0.0742 \mathrm{TPC}-0.0043 \mathrm{TF}+0.0007 \mathrm{~A}+0.9972 \mathrm{Ch}-6.244 \times 10^{-33} \mathrm{VC}
$$


As PC1 accounted for most of the data variability, we infer that its factor loadings (component loadings in PCA or the correlation coefficients between the variables and factors) are adequate indicators of correlation [26]. For factor "Cultivars" (G), Ch (SPAD Chlorophyll Units) showed the highest correlation $\left(0.9972\right.$, with $\left.R^{2}=0.994\right)$, followed by TPC, the second variable in importance for the PCA. On the contrary, A and TF reflected low loadings, and VC evidenced a negligible weight.

The observed tendency between DK and TPC for genotypes shows a significant positive linear correlation $(p \leq 0.05)$ (Table 4). Evidence suggests that the interaction between the genotype and the doses of $\mathrm{K}^{+}(\mathrm{G} \times \mathrm{DK})$ (Figure 2$)$ was highly significant $(p \leq 0.001)$ for the content of TPC. Genotypes showed a lineal increase in the phenolic content by increasing the doses of $\mathrm{K}^{+}$. To correlate the content of nutraceutical compounds and the antioxidant capacity, a regression analysis was carried out. The TPC had significant positive correlation with flavonoids $(r=0.822)$ and anthocyanins $(r=0.757)$ (Table 5), since an increased production of them contribute to the increase of the TPC concentration. There was also a significant positive correlation $(r=0.979)$ among the content of flavonoids and anthocyanins, since anthocyanins are classified as a class of flavonoids derived ultimately from phenylalanine [27], indicating that the increase of flavonoids is influenced by the increase of anthocyanins. Vitamin $\mathrm{C}$ also showed a significant positive correlation with total flavonoids $(r=0.708)$ and anthocyanins $(r=0.682)$, which could be explained in terms of the synthesis of vitamin $C$, produced from nonstructural carbohydrates compounds and phenylpropanoids precursors [11]. The antioxidant capacity had a positive correlation with flavonoids $(r=0.621)$, and anthocyanins $(r=0.655)$, but a low correlation with TPC $(r=0.549)$. As mentioned above, other methods of analysis, such as ABTS, FRAP and ORAC, are necessary to establish a conclusive correlation between the antioxidant activity and the content of bioactive compounds produced by additional $\mathrm{K}^{+}$.

Table 4. Determination coefficients $\left(R^{2}\right)$ between doses of $K^{+}(\mathrm{DK})$ and nutraceutical contents in cultivars of hydroponic basil.

\begin{tabular}{cccc}
\hline Nutraceutical Contents & \multicolumn{3}{c}{ Cultivars } \\
\hline & CN & SL & RR \\
\hline DK-TPC & $0.970^{* *}$ & $0.950^{* *}$ & $0.998^{* *}$ \\
DK-TF & $0.993^{* *}$ & $0.993^{* *}$ & $0.998^{* *}$ \\
DK-A & $0.982^{* *}$ & $0.973^{* *}$ & $0.983^{* *}$ \\
DK-Ch & $0.109^{\mathrm{ns}}$ & $0.198 \mathrm{~ns}$ & $0.107_{\mathrm{ns}}$ \\
DK-VC & $0.723^{*}$ & $0.847^{* *}$ & $0.847^{* *}$ \\
DK-AC & $0.988^{* *}$ & $0.867^{* *}$ & $0.923^{* *}$ \\
\hline
\end{tabular}

*: $p \leq 0.05 ; * *: p \leq 0.01$; ns: non-significant; CN: "Cinnamon"; SL: "Sweet Lemon"; RR: "Red Rubin"; TPC: Total phenolic compounds; TF: Total flavonoids; A: Anthocyanins; Ch: SPAD chlorophyll units; VC: Vitamin C; AC: Antioxidant capacity; ns: non-significant.

Table 5. Pearson correlation coefficient $(r)$ estimated among nutraceutical compounds and antioxidant capacity of hydroponic basil.

\begin{tabular}{ccccccc}
\hline Parameters & TPC & TF & A & Ch & VC & AC \\
\hline TPC & 1 & & & & & \\
TF & $0.822^{*}$ & 1 & & & & \\
A & $0.757^{*}$ & $0.979^{*}$ & 1 & & & \\
Ch & 0.344 & 0.288 & 0.144 & 1 & & \\
VC & 0.523 & $0.708^{*}$ & $0.682^{*}$ & 0.291 & 1 & \\
AC & 0.549 & $0.621^{*}$ & $0.655^{*}$ & -0.206 & 0.304 & 1
\end{tabular}

* Significant at $p \leq 0.05$; TPC: Total phenolic compounds; TF: Total flavonoids; A: Anthocyanins; Ch: SPAD chlorophyll units; VC: Vitamin C; AC: Antioxidant capacity.

\subsection{Antioxidant Capacity}

The antioxidant capacity (AC) showed no significant differences in relation to $\mathrm{G}$ but significant differences for DK $(p \leq 0.05)$ (Figure 3). 


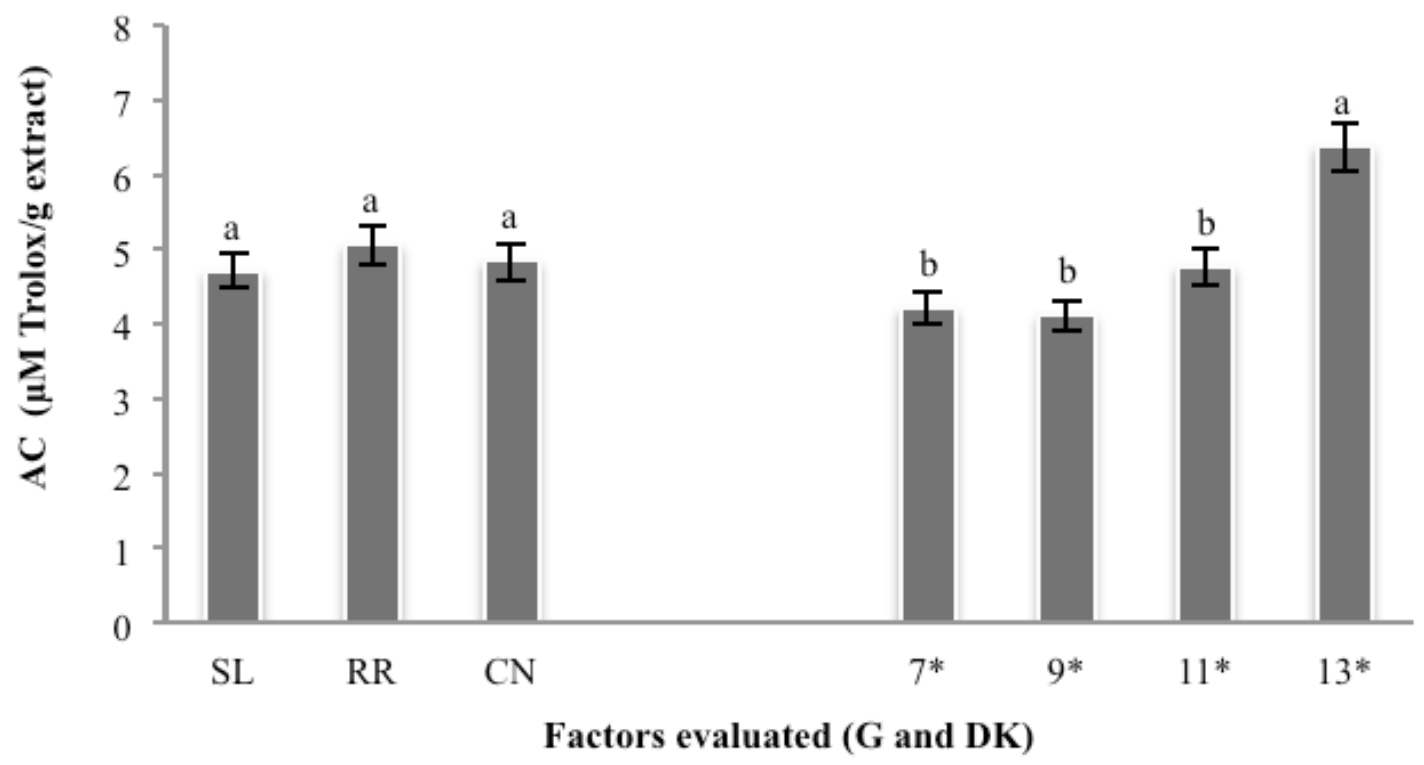

Figure 3. Effects caused by Genotype (G) and $\mathrm{K}^{+}$dose (DK) on the Antioxidant Capacity (AC) of hydroponic basil. Different letter between column and factor indicated significant differences according to Tukey test $(p \leq 0.05)$. SL: "Sweet Lemon"; RR: "Red Rubin"; CN: “Cinnamon"; *: mmol.L-1. Interval bars are the standard error.

\subsection{Interaction Analysis}

The interaction $G \times D K$ was highly significant $(p \leq 0.001)$ (Figure 4$)$, indicating that one or more doses of $\mathrm{K}^{+}$used affects the assessed cultivars. Figure 4 shows that AC obtained for "Red Rubin" presented a linear increase for increased doses of $\mathrm{K}^{+}$in the interval studied.

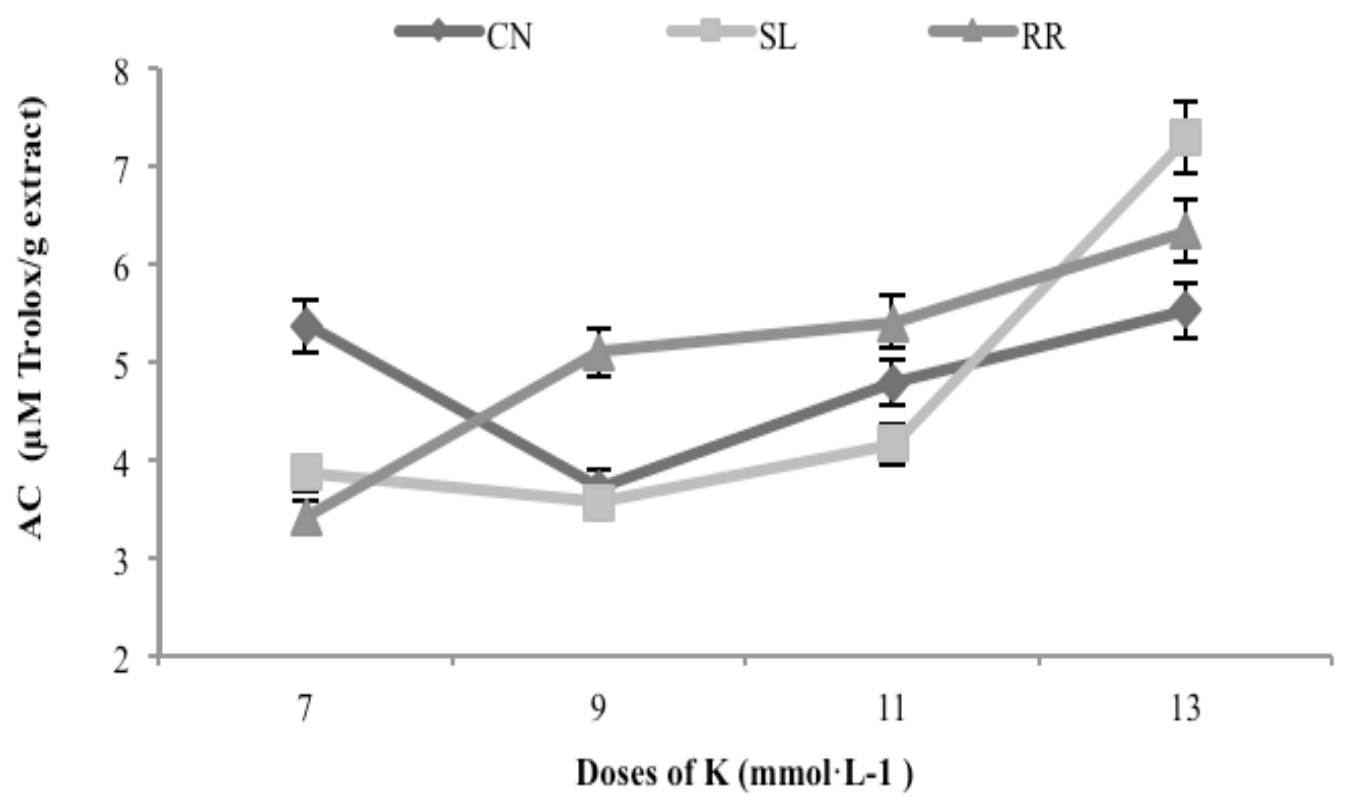

Figure 4. Effects caused by interaction of Genotype and doses of $\mathrm{K}^{+}(\mathrm{G} \times \mathrm{DK})$ for Antioxidant Capacity (AC) of hydroponic basil. CN: "Cinnamon"; SL: "Sweet Lemon"; RR: "Red Rubin". Interval bars are the standard error. 


\section{Discussion}

\subsection{Total Phenolic Compounds, Flavonoids and Anthocyanins Content}

Several authors report differences in the phenolic content of cultivars given by their genetic characteristics. In this sense, Ibrahim et al. [11] reported an increase of 1.22 to $1.82 \mathrm{mg}$ GAE/g extract when applying 0 to $270 \mathrm{~kg}$ of $\mathrm{K}^{+} /$ha in Labisia pumila Benth, and also obtained similar results for flavonoids, reporting values from 0.68 to $0.94 \mathrm{mg} \mathrm{g}^{-1}$ of rutin in leaves of this plant by increasing $\mathrm{K}^{+}$. Flanigan and Niemeyer [13] found values from 13.1 to $26.9 \mathrm{mg}$ GAE/g DW for ten basil cultivars. Javanmardi et al. [14] studied the total phenolic compounds in 23 different cultivars of basil, cultivated in different places, and reported values from 22.9 to $65.5 \mathrm{mg} \mathrm{GAE} / \mathrm{g}$ dry weight (DW). Moreover, Kwee and Niemeyer [28] in a study of 15 cultivars of basil in greenhouse, reported an interval from 3.47 to $17.58 \mathrm{mg}$ GAE/g DW. The obtained results are in agreement with the data reported by Nguyen et al. [29], who evaluated $\mathrm{K}^{+}$concentrations from 1 to $5 \mathrm{mM}$ and reported values of phenolic compounds from 7 to $16 \mathrm{mg} \mathrm{GAE} / \mathrm{g}$ DW. For anthocyanins, the results obtained in this work are similar to those reported by Lee and Scagel [18], who found an average of $0.65 \mathrm{mg} / \mathrm{g}$ DW in basil, and are also concordant to some studies that suggest that anthocyanins in red leaf cultivars are higher when compared to green leaf cultivars. In this sense, significant differences in total anthocyanin concentration have been observed between purple basil varieties, from 16.63 to $18.78 \mathrm{mg} / 100 \mathrm{~g}$ of fresh tissue [30].

On the other hand, $\mathrm{K}^{+}$as enzymatic activator stimulates the synthesis of pigments, including anthocyanins [31]. Accordingly, the gained results suggest that the highest content of anthocyanins was observed in the $\mathrm{K}^{+}$concentration of $13 \mathrm{mmol} \cdot \mathrm{L}^{-1}(0.79 \mathrm{mg} \mathrm{AE} / \mathrm{g}$ extract), followed by 11,9 and $7 \mathrm{mmol} \cdot \mathrm{L}^{-1}(0.745,0.696$ and $0.645 \mathrm{mg} \mathrm{AE} / \mathrm{g}$ extract, respectively). Therefore, our results were similar to the trend observed for total phenolic and flavonoid compounds, as can be inferred by the linear regression and determination coefficients, $R^{2}>0.97$ (Table 2).

In the same way as the total content of phenolic compounds, the increased of flavonoid and anthocyanins content might be due to an increase in total nonstructural carbohydrates. The response of $\mathrm{K}^{+}$to these compounds might be due to a maximum accumulation of nonstructural carbohydrates given by translocation of the ion $\mathrm{K}^{+}$to formation of phenyl-propanoids [11]. Once in the cytosol, $\mathrm{K}^{+}$can cross the tonoplast through conveyors or channels which are responsible for its influx into vacuoles, while channels mainly mediate its outflow to the cytosol by antiporters which catalyze the electroneutral exchange of $\mathrm{K}^{+}$and $\mathrm{H}^{+}$using an electrochemical gradient produced by $\mathrm{H}^{+}$-ATPase present in the plasma membrane of cell organelles [32,33]. This could explain that ion $\mathrm{K}^{+}$was redirected to its various functions, and due to the intense mobility in phloem and xylem was possible to regulate the internal balance for absorption and translocation of carbohydrates, affecting indirectly the formation of the basic structures of phenyl-propanoids. However, despite a linear increase of TPC with DK was observed, this tendency should decline when reaching certain $\mathrm{K}^{+}$doses, and, thus, could be interesting to extend the range of DK to find a non-linear response to relate the doses of $\mathrm{K}^{+}$with the production of total phenolic compounds.

\subsection{Chlorophyll}

The gained results about chlorophyll responses may be explained by the genetic variability evidenced by the studied cultivars. San Miguel-Chavez et al. [34] studied the effect of $\mathrm{K}^{+}$on the chlorophyll content of three varieties of Amarantnhus hypochondriacus L. They found increases of chlorophyll in two cultivars under increase of $\mathrm{K}^{+}$, while one of the cultivars did not show significant differences with treatments, which were set from 0 to $6 \mathrm{mmol} \cdot \mathrm{L}^{-1}$. These authors concluded that the apparent lack of availability of $\mathrm{K}^{+}$in the substrate possibly produced marginal chlorosis of leaves; in this context, there were differences in chlorophyll content when the availability of $\mathrm{K}^{+}$was increased. We suggest that the different assayed doses of $\mathrm{K}^{+}$did not affect the photosynthetic process of the plant, and therefore all of them were sufficient for normal development, allowing not only the maintenance 
of the osmotic potential in cells, but also the stomata opening and closing. $\mathrm{K}^{+}$is transported through the membranes of guard cells, opening it when increasing its concentration, which is influenced the enzymatic activation and therefore a greater concentration of this nutraceutical compound [35].

\subsection{Vitamin C}

Several possible routes for the synthesis of vitamin $C$ has been described for plants, such as the route of Smirnoff-Wheeler (conducted by various glucidic routes), the route of D-galacturonic acid (derived from pectins), the route of mio-inositol (in Arabidopsis) and the route of D-glucose (via L-sorbosona), which is a reaction dependent of power reducing (NADP+) [36,37]. All these routes require large amounts of energy and power, reducing the possibility of taking place. $\mathrm{K}^{+}$may be involved in these routes, because it is the most abundant cation present in the phloem sap (almost $80 \%$ of the totals cations) and plays a role directly in the process of loading/transport of non-structural carbohydrates through the phloem to sink organs [38]. Yurtseven et al. [39] reported the effect of different $\mathrm{K}^{+}$doses on the growth and quality of tomato, concluding that increased $\mathrm{K}^{+}$doses in the nutrient solution produce increased contents of vitamin $\mathrm{C}$. Therefore, $\mathrm{K}^{+}$plays a key role in the metabolism of carbohydrates and photosynthesis, and consequently, an optimal supply of $\mathrm{K}^{+}$could determine higher sugar content in sink organs and therefore higher contents of vitamin $\mathrm{C}$, improving the quality of the product.

Then, it can be inferred that the synthesis of vitamin $C$ in the studied basil genotypes was mostly favored when applying higher $\mathrm{K}^{+}$doses. These results are supported by the estimated $R^{2}$ values obtained in the linear correlation between DK and vitamin C content (Table 3). Ali et al. [40] arrived to the same conclusion, reporting that the content of vitamin $C$ in berries and kiwis was improved substantially by applying high concentrations of $\mathrm{K}^{+}$.

\subsection{Antioxidant Capacity}

The antioxidant capacity of basil has been reported in several studies [12,28,41], showing that, regardless of cultivar, basil is a species with high potential as a source of bioactive compounds with antioxidant capacity. This conclusion can also be derived, as a significant positive correlation between DK and AC for all cultivars was obtained (Table 3). Therefore, manipulation of $\mathrm{K}^{+}$in the nutrient solution can be a viable option for improving nutraceutical qualities of basil. Under this premise, results suggest that, with doses 7,9 and $11 \mathrm{mmol} \cdot \mathrm{L}^{-1}$, a similar response was obtained, implying a significant increase similar to that with the highest dose. "Cinnamon" and "Sweet Lemon" evidenced such linear increase for the $9-11 \mathrm{mmol} \cdot \mathrm{L}^{-1}$ interval $\left(R^{2}=0.988\right.$ and 0.867 , respectively), while AC decreased from 7 to $9 \mathrm{mmol} \cdot \mathrm{L}^{-1}$. In this sense, a different response of cultivars was observed when DK was increased from 7 to $9 \mathrm{mmol} \cdot \mathrm{L}^{-1}$.

Nevertheless, these results could depend on the method of analysis used to determine the antioxidant capacity. Thus, to compare results and determine the correlation among bioactive compounds by an induced control of $\mathrm{K}^{+}$, we strongly recommend in future studies to use other methods for the analysis of antioxidant capacity, such as ABTS, FRAP and ORAC.

\section{Conclusions}

A hydroponic system was designed for the production of nutraceuticals, as an alternative option for suitable use of resources, to create value-added, which is particularly important in semiarid regions. It was demonstrated that the content of the analyzed nutraceutical components could be improved by cultivar selection and by increasing the content of $\mathrm{K}^{+}$during plant growth. Significant linear correlation was obtained between the doses of $\mathrm{K}^{+}$applied and the total content of phenolic compounds, flavonoids, anthocyanins, chlorophylls and vitamin $\mathrm{C}$, for the three basil genotypes investigated. In this context, further studies should be approached to determine the $\mathrm{K}^{+}$doses that maximize the synthesis of these bioactive compounds. 
In relation to the antioxidant capacity of hydroponic basil, the DPPH test suggests a positive linear tendency for increased doses of $\mathrm{K}^{+}$. Nevertheless, due to the influence of the method applied to measure the antioxidant activity, other antioxidant tests (ABTS, FRAP, and ORAC) should be selected in future studies to determine a certain correlation between the effect of $\mathrm{K}^{+}$and the antioxidant activity of basil cultivars.

Acknowledgments: Lilia Salas-Pérez acknowledges financial support given by the National Council for Science and Technology (CONACYT) of México. Authors thank the collaborative support and assistance of the Water and Soil Analysis Lab technicians of Torreón Technological Institute, Juárez de Durango State University and Center for Biological Research of Northwest Mexico.

Author Contributions: Lilia Salas-Pérez and José L. García-Hernández conceived and designed the experiments; Lilia Salas-Pérez and Tiziana Fornari-Reale performed the experiments; Pablo Preciado-Rangel and Enrique Troyo-Diéguez analyzed the data; Esteban Sánchez-Chávez contributed reagents, materials and analytical tools; and Enrique Troyo-Diéguez and Pablo Preciado-Rangel wrote the paper.

Conflicts of Interest: The authors declare no conflicts of interest.

\section{References}

1. Tilman, D.; Clark, M. Global diets link environmental sustainability and human health. Nature 2014, 515, 518-522. [CrossRef] [PubMed]

2. Popkin, B.M.; Adair, L.S.; Ng, S.W. Global nutrition transition and the pandemic of obesity in developing countries. Nutr. Rev. 2012, 70, 3-21. [CrossRef] [PubMed]

3. Cardeñosa, V.; Barreira, J.; Barros, L.; Arenas-Arenas, F.; Moreno-Rojas, J.; Ferreira, I. Variety and Harvesting Season Effects on Antioxidant Activity and Vitamins Content of Citrus sinensis Macfad. Molecules 2015, 20, 8287-8302. [CrossRef] [PubMed]

4. Wang, M.; Fu, Y.; Liu, H. Nutritional status and ion uptake response of Gynura bicolor DC between Porous-tube and traditional hydroponic growth systems. Acta Astronaut. 2015, 113, 13-21. [CrossRef]

5. Katsoulas, N.; Savvas, D.; Kitta, E.; Bartzanas, T.; Kittas, C. Extension and evaluation of a model for automatic drainage solution management in tomato crops grown in semi-closed hydroponic systems. Comput. Electron. Agric. 2015, 113, 61-71. [CrossRef]

6. Sgherri, C.; Cecconami, S.; Pinzino, C.; Navari-Izzo, F.; Izzo, R. Levels of antioxidants and nutraceuticals in basil grown in hydroponics and soil. Food Chem. 2010, 123, 416-422. [CrossRef]

7. Constán-Aguilar, C.; Leyva, R.; Blasco, B.; Sánchez-Rodríguez, E.; Soriano, T.; Ruiz, J.M. Biofortification with potassium: Antioxidant responses during postharvest of cherry tomato fruits in cold storage. Acta Physiol. Plant. 2014, 36, 283-293. [CrossRef]

8. Demiral, M.A.; Küseoglu, A.T. Effect of Potassium on Yield, Fruit Quality, and Chemical Composition of Greenhouse-Grown Galia Melon. J. Plant Nutr. 2005, 28, 93-100. [CrossRef]

9. Lester, G.E.; Jifon, J.L.; Makus, D.J. Impact of potassium nutrition on postharvest fruit quality: Melon (Cucumis melo L.) case study. Plant Soil 2010, 335, 117-131. [CrossRef]

10. Devi, B.S.R.; Kim, Y.J.; Selvi, S.K.; Gayathri, S.; Altanzul, K.; Parvin, S.; Yang, D.U.; Lee, O.R.; Lee, S.; Yang, D.C. Influence of potassium nitrate on antioxidant level and secondary metabolite genes under cold stress in Panax ginseng. Russ. J. Plant Phys. 2012, 59, 318-325. [CrossRef]

11. Ibrahim, M.; Jaafar, H.; Karimi, E.; Ghasemzadeh, A. Primary, secondary metabolites, photosynthetic capacity and antioxidant activity of the Malaysian herb Kacip Fatimah (Labisia pumila Benth) exposed to potassium fertilization under greenhouse conditions. Int. J. Mol. Sci. 2012, 13, 15321-15342. [CrossRef] [PubMed]

12. Al-Kateb, H.; Mottram, D.S. The relationship between growth stages and aroma composition of lemon basil Ocimum citriodorum Vis. Food Chem. 2014, 152, 440-446. [CrossRef] [PubMed]

13. Flanigan, P.M.; Niemeyer, E.D. Effect of cultivar on phenolic levels, anthocyanin composition, and antioxidant properties in purple basil (Ocimum basilicum L.). Food Chem. 2014, 164, 518-526. [CrossRef] [PubMed]

14. Javanmardi, J.; Stushnoff, C.; Locke, E.; Vivanco, J.M. Antioxidant activity and total phenolic content of Iranian Ocimum accessions. Food Chem. 2003, 83, 547-550. [CrossRef]

15. Inzunza-López, J.O.; López-Ariza, B.; Valdez-Cepeda, R.D.; Mendoza, B.; Sánchez-Cohen, I.; García-Herrera, G. La variación de las temperaturas extremas en la Comarca Lagunera y cercanías. Rev. Chapingo Ser. Cienc. For. Ambient. 2011, 17, 45-61. [CrossRef] 
16. Atmospheric Science Data Center (ASDC). NASA Surface Meteorology and Solar Energy-Location. NASA Langley Research Center. USA. Available online: https:/ / eosweb.larc.nasa.gov/cgi-bin/sse/grid. cgi?email=skip@larc.nasa.gov (accessed on 27 October 2017).

17. Comisión Nacional del Agua (CONAGUA). Servicio Meteorológico Nacional—Normales Climatológicas. México. Available online: http://smn.cna.gob.mx/es/component/content/article?id=42 (accessed on 27 October 2017).

18. Lee, J.; Scagel, C.F. Chicoric acid found in basil (Ocimum basilicum L.) leaves. Food Chem. 2009, 115, 650-656. [CrossRef]

19. Steiner, A.A. A universal method for preparing nutrient solutions of a certain desired composition. Plant Soil 1961, 15, 134-154. [CrossRef]

20. Rivera, J.R.E.; Stone, M.B.; Stushnoff, C.; Pilon-Smits, E.; Kendall, P.A. Effects of ascorbic acid applied by two hydrocooling methods on physical and chemical properties of green leaf lettuce stored at 5 C. J. Food Sci. 2006, 71, 270-276. [CrossRef]

21. Zhishen, J.; Mengcheng, T.; Jianming, W. The determination of flavonoid contents in mulberry and their scavenging effects on superoxide radicals. Food Chem. 1999, 64, 555-559. [CrossRef]

22. Abdel-Aal, E.S.M.; Hucl, P. A rapid method for quantifying total anthocyanins in blue aleurone and purple pericarp wheats. Cereal Chem. 1999, 76, 350-354. [CrossRef]

23. Asai, H.; Samson, B.K.; Stephan, H.M.; Songyikhangsuthor, K.; Homma, K.; Kiyono, Y.; Inove, Y.; Shiraiwa, T.; Horie, T. Biochar amendment techniques for upland rice production in Northern Laos: 1. Soil physical properties, leaf SPAD and grain yield. Field Crop Res. 2009, 111, 81-84. [CrossRef]

24. Davis, S.H.R.; Masten, S.J. Spectrophotometric method for ascorbic acid using dichlorophenolindophenol: Elimination of the interference due to iron. Anal. Chim. Acta 1991, 248, 225-227. [CrossRef]

25. Brand-Williams, W.; Cuvelier, M.E.; Berset, C. Use of a free radical method to evaluate antioxidant activity. Lebensm. Wiss. Technol. 1995, 28, 25-30. [CrossRef]

26. Statistical Analysis System (SAS). SAS/STAT ${ }^{\circledR}$ 9.2. In User's Guide; SAS Institute Inc.: Cary, NC, USA, 2008; 74p.

27. Tanaka, Y.; Sasaki, N.; Ohmiya, A. Biosynthesis of plant pigments: Anthocyanins, betalains and carotenoids. Plant J. 2008, 54, 733-749. [CrossRef] [PubMed]

28. Kwee, E.M.; Niemeyer, E.D. Variations in phenolic composition and antioxidant properties among 15 basil (Ocimum basilicum L.) cultivars. Food Chem. 2011, 128, 1044-1050. [CrossRef]

29. Nguyen, P.M.; Kwee, E.M.; Niemeyer, E.D. Potassium rate alters the antioxidant capacity and phenolic concentration of basil (Ocimum basilicum L.) leaves. Food Chem. 2010, 123, 1235-1241. [CrossRef]

30. Phippen, W.B.; Simon, J.E. Anthocyanins in basil (Ocimum basilicum L.). J. Agric. Food Chem. 1998, 46, 1734-1738. [CrossRef]

31. Kong, J.M.; Chia, L.S.; Goh, N.K.; Chia, T.F.; Brouillard, R. Analysis and biological activities of anthocyanins. Phytochemistry 2003, 64, 923-933. [CrossRef]

32. Finazzi, G.; Petroutsos, D.; Tomizioli, M.; Flori, S.; Sautron, E.; Villanova, V.; Rolland, N.; Seigneurin-Berny, D. Ions channels/transporters and chloroplast regulation. Cell Calcium 2015, 58, 86-97. [CrossRef] [PubMed]

33. Xu, H.; Martinoia, E.; Szabo, I. Organellar channels and transporters. Cell Calcium 2015, 58, 1-10. [CrossRef] [PubMed]

34. San Miguel-Chávez, R.; Hernández-Sequera, V.; Rosas-Calleja, D.; Trinidad-Santos, A.; Larqué-Saavedra, A. Efecto del potasio sobre la conductancia estomatica y contenido de clorofila en Amaranto (Amaranthus hypochondriacus L.). Rev. Chapingo Ser. Hortic. 1999, 5, 19-22. [CrossRef]

35. Limantara, L.; Dettling, M.; Indrawati, R.; Brotosudarmo, T.H.P. Analysis on the Chlorophyll Content of Commercial Green Leafy Vegetables. Proc. Chem. Soc. 2015, 14, 225-231. [CrossRef]

36. Loewus, F.A. Biosynthesis and metabolism of ascorbic acid in plants and of analogs of ascorbic acid in fungi. Phytochemistry 1999, 52, 193-210. [CrossRef]

37. Pignocchi, C.; Foyer, C.H. Apoplastic ascorbate metabolism and its role in the regulation of cell signalling. Curr. Opin. Plant Biol. 2003, 6, 379-389. [CrossRef]

38. Cakmak, I. Potassium for better crop production and quality. Plant Soil 2010, 335, 1-2. [CrossRef]

39. Yurtseven, E.; Kesmez, G.D.; Ünlükara, A. The effects of water salinity and potassium levels on yield, fruit quality and water consumption of a native central anatolian tomato species (Lycopersicon esculantum). Agric. Water Manag. 2005, 78, 128-135. [CrossRef] 
40. Ali, L.; Alsanius, B.W.; Rosberg, A.K.; Svensson, B.; Nielsen, T.; Olsson, M.E. Effects of nutrition strategy on the levels of nutrients and bioactive compounds in blackberries. Eur. Food Res. Technol. 2012, 234, $33-44$. [CrossRef]

41. Koca, N.; Karaman, S. The effects of plant growth regulators and 1-phenylalanine on phenolic compounds of sweet basil. Food Chem. 2015, 166, 515-521. [CrossRef] [PubMed] 